\section{LIFE IN AGONY: THE CITY AS PORTRAYED IN MODERNIST THAI SHORT STORIES (1964-1973)}

\section{Irrawadee Tailanga ${ }^{1}$}

\begin{abstract}
This study attempts to investigate changes, both in content and form, evidenced in a remarkable number of Thai short stories from 1964 to 1973. These Thai short stories express an estrangement from urbanism as well as hostility towards westernization, the establishment, and dictatorship. The themes of alienation, bleakness, and despair, which are reactions to urbanization, are common. In terms of change in form, rejection of the representational conventions of realism and the disruption of the unity and causality of plot structure are apparent. The works of this period explore the inner self through various techniques. There is also an increase in the use of experimental modes of expression as influenced by the arts. Most works in this period show an interest in sophistication and mannerism. This transformation of Thai short stories reveals the influence of modernist literary works from the West.
\end{abstract}

\section{Introduction}

The Thai Literary Circle confronted a great deal of hardship under consecutive autocratic governments led by Sarit Thanarat and Thanom Kittikhachon between 1958-1973. Freedom of speech

1 Associate Professor, Department of Literature, Faculty of Humanities, Kasetsart University, Bangkok was limited and a lot of writers and freedom fighters were arrested. Most literary works at the time were escape literature, which aimed at pure entertainment. To make matters worse for newcomers to the literary circle, established publishers accepted only works written by famous writers or those created according to their 'standard'.

Likewise, freedom of speech was minimal in the universities. But some students managed to express themselves creatively through certain activity groups such as book clubs, where literary magazines originated as early as 1961. By then, student magazines or small magazines had seen significant growth. ${ }^{2}$ Many small magazines were distributed by student groups and clubs under changing titles, which was a way to avoid the rigid control brought about by publication legislation at the time. These magazines gave the students a rare space where they could express their opinions, publish their creative literary works and seek out an audience. The kinds of works that appeared in such journals were poetry, short stories, and articles. In the early period, a considerable number of literary works in these magazines were written both by famous writers and by inexperienced students emulating the writing fashion of the moment.

But by 1964, students' short stories exhibited radical changes in content and form. These works, which dared to experiment with new styles, were far more

\footnotetext{
${ }^{2}$ It should be noted here that in the West, the works which have been accepted as modernism originally sought their way into publication through the little magazines. These magazines, though limited in readership, created the new movement in literature and various arts (Bradbury and McFarlane, 1985:203).
} 
sophisticated than those of standard publishing houses, such as a group of short stories called The Glassless Spectacles (1964) by Nipon Jitrakum, then a student of Silpakorn University, now regarded as a milestone of the surrealistic style.

Most experimental short stories are representations of life in the city. The four anthologies compiled by Suchart Sawadsi in 1975 and 1976, namely Harsh Drought, The Road That Leads to Death, The Response, and Like It Has Never Been Done Before, reveal that the styles of the short stories are varied. While the styles of short stories in other anthologies are quite traditional, The Road That Leads to Death, the anthology of 1964-1975 short stories concerning the city, is replete with innovative stylized pieces of writing. It can be assumed that new modes of expression were needed for a more effective articulation of the kind of tension and confusion of the city felt at that time. This relationship between the new forms of modernist works and modernization has been discussed widely by scholars; the radically altered quality of city life obligated a change in artistic means of expression, so there are deep connections between modernism and modern urban rhythm (Eysteinsson, 1990: 20). It is of especial interest that the styles of Thai short stories in this period resemble those of modernist literary works of the West.

\section{Modernism: An Art of the City}

Various literary figures suggest that modernism $^{3}$ is an art of the city. Malcolm

\footnotetext{
3 The term has been used to the cover the international movement in the early twentieth century, which breaks from established literary and artistic rules and conventions. Modernism moves toward mannerism, introversion, and
}

Bradbury discusses the theme of the city in 'The City of Modernism' in Modernism 1890-1930. Cities are centers of intellectual and cultural activities. And at the same time metropolitan life is an environment of complexity and tension:

Modernism is a particularly
urban art, that is partly because
the modern artist, like his
fellow men, has been caught
up in the spirit of the modern
city, which is itself the spirit of
a modern technological
society. [...] The city has
become culture, or perhaps the
chaos that succeeds it
(Bradbury and McFarland,
1985:97).

Raymond Williams, in 'Metropolitan Perceptions and the Emergence of Modernism' published in The Politics of Modernism, proposes that technological change in the modern era transforms the city into a metropolitan center. In response to new environments, certain themes in art and thought develop. He then gives the examples of these themes as follows: the modern city as a gathering of strangers, the lonely and isolated individual within the crowd, the impenetrability of the city, new kinds of human solidarity, and escape to a more peaceful and innocent rural refuge (Williams, 1989:37-63). Likewise, Peter Childs concludes that characteristics of modernism are a focus on the city and a fear of technology, expressed in a radical stylistic innovation (Childs, 2000:19).

\footnotetext{
technical display (i.e. anti-representationalism in painting, stream-of-consciousness narrative in fiction). It also suggests concepts of bleakness, darkness, and alienation (Bradbury and McFarland, 1985:26).
} 


\section{Thai Short Stories and Urbanization}

Thailand under the consecutive dictatorial regimes of Field Marshal Pibulsongkhram and Sarit Thanarat embraced modern changes introduced by the United States after the Second World War. Under the Sarit Thanarat regime, the construction of an infrastructure, a new economic system and institutions, foreign investment, and a market economy were actively promoted by government policy. Flowing tap water, extension of electrification, wide roads, employment opportunities, and cleanliness were thus promoted.

On the other hand, the acceleration of modernization caused damage to the way of life and culture of the Thai people. Industrialization and a capitalist economic system replaced peaceful villages with overcrowded urban centers, poverty, filthiness, etc.

A certain number of short stories bear witness to the writers' disapproval of such changes. The short stories which express a negative impression of the cities come from writers who were migrants. Moving from rural areas to study or find jobs, these people became alienated to the developing city. They not only stated in the content of the stories the loathing of the city but also articulated their feelings via new styles of writing. Raymond Williams notes that alienation causes innovation in form: 'The most important general element of the innovations in forms is the fact of migration to the metropolis, and it cannot too often be emphasized how many of the major innovators were, in this precise sense, immigrants' (Williams, 1989:45). Notable writers who migrated to the city and wrote stories in innovative styles were, to name a few, Suchart Sawadsi, Surachai
Chantimatorn, Nikom Rayawa, and Witayakorn Chiangkul. Removed from familiar provincial culture and faced with a new and alienated urban environment, these writers found comfort in writing. Appearing first in small magazines, their works later achieved distinction.

The rapid change of Bangkok and vicinity is clearly depicted in the three literary works by Rong Wongsawan: The Carefree Peasants (1969), Those Who Have Yikae in Their Hearts (1969) and Climbing Up the Canal Banks (1972). The Carefree Peasants was originally published in Sayamrut Weekly Magazine in the late 1950 s. It is a series of short stories about the peaceful life of rural people living in the outskirts of Bangkok, Nonthaburi and Pathum Thani. The stories revolve around a group of people whose lives are simple and self-sustainable. Despite being poor, these characters manage to live their lives happily by hunting and gathering edible plants for food from their surroundings and idling away their spare time. Thus, many episodes are about exotic recipes and a rural way of life unfamiliar to urban people. The series later continues in a sequel called Those Who Have Yikae in Their Hearts.

Returning to Thailand from San Francisco, where he had lived from 1963-1967, Rong Wongsawan wrote another series of short stories called Climbing Up the Canal Banks. The series is about the changes in provincial areas; urbanized provinces follow the fate of Bangkok. Urban sprawl leads land brokers to the countryside; the villagers are mesmerized by their alluring deals. Plots of land are sold one after another and the villagers enjoy being wealthy overnight. They spend money extravagantly and imitate the modern life of Bangkokians. They want to buy cars although the only way to reach home is by 
boat. They dress fashionably, eat fancy food, and hang out in nightclubs. As the narrator puts it:

The circumstances of change were harsh, like a drama which was written with the blood of a bleeding heart on a sheet of white paper. The arrival of the land brokers and constructors affirmed that modernization was setting in. Money, money, money; the aroma of money excited everyone. Uncle Sin, the fisherman, felt elated when was called 'Khun Worasin' by a Bangkokian; because he had a piece of land stood in the way of another huge plot of land $^{4}$ (Rong Wongsawan, 1990:64).

Narrated in a sarcastic tone, Climbing $U p$ the Canal Banks exposes the fate of the villages and their inhabitants. The once peaceful villages soon deteriorate; the inhabitants lose their land and finally go bankrupt. It is hardly surprising that these landless people end up migrating to the city and becoming laborers.

\section{Change of the City: from Flawless to Filthy}

A number of Thai short stories show how cities had been changing because of modernization even before Rong Wongsawan's Climbing Up the Canal Banks. In 1970, Suchart Sawadsi wrote 'A Walk to the Fields' (collected in The Silence (1972)), showing the change of life in the suburbs. Provincial people migrate to the cities looking for jobs. Skyscrapers replace rice fields. People prefer foreign

\footnotetext{
${ }^{4}$ All extracts in this article were translated by Irrawadee Tailanga.
}

products believing that they represent a higher standard of life. All the changes are captured vividly in these short stories. As Suchart Sawadsi puts it:

If the rice field I was looking at had once been a virgin, now she lost her virginity to a man called modernization. The road from the market was cut through row houses into the rice field which was being developed into a housing estate. [...] Electricity poles were everywhere; the power lines were connected and ended near a hut in the field. Row houses and a school were being built. At the other end an advertisement of land sale by installments popped up together with signs selling rice threshing machines and motorcycles from Japan. Television antennae rose haphazardly above the rooftops of houses along the canal (Suchart Sawadsi, 1972:126).

In the same collection, the story titled 'Out of the Darkness' is a satire of city life. The story focuses on the poor transportation in Bangkok. The setting of the story is on a crowded bus standing still in a traffic jam. The narrator manages to survive the boredom by daydreaming. He describes the passengers on the bus as goods packed in a big box, sardines in a can, or meat hanging in a market:

O.K. Close your eyes and prepare yourself for a journey with me. The box is quite packed. But before long we will embrace the 'tin can culture' in our lives. We -you and I -- are thrown about with it. We hardly move, for a woman's boobs are sticking on my back. You may not be able to move your 
legs. I look at a row of arms hanging from the rails; some are straight, some bent at the elbow. They look like pieces of meat hanging from hooks at the market stalls. I wonder if it is our flesh that is hanging from the rail, or if it is the rail that holding our flesh. We are stuck to it from the front to the rear (Suchart Sawadsi, 1972:202).

As the above quotation describes the state of the crowded bus, it offers a surrealistic image of dangling meat that emphasizes the dehumanized condition of the city. José Ortega y Gasset in The Dehumanization of Arts suggests that the modern artist is seen going against reality: 'he is brazenly set on deforming reality, shattering its human aspect, dehumanizing it' (Ortega y Gasset, 1968:21).

Later, when the narrator reaches his office, the depression caused by the workplace rules and formality is unavoidable. The narrator compares the tolerance one must have working in the city with sardines in a tin can: 'And you have to accept the tin-can conduct twice a day; we get used to the ruled, controlled, forced condition. And we forget the real meaning of freedom; being free to roll over in an open field' (Suchart Sawadsi, 1972:202).

This relentless modernization spreads to the provinces, like Nakhorn Ratchasima and Udon Thani. Airfields were built where the Thai government deemed necessary, readily collaborating with the United States during the Indo-Chinese War. Peaceful provinces like Udon Thani were altered to suit the needs of the Americans. The short story 'Haun's Smile' (1970) by Korn Krailard shows that the province's simple way of life is changed. It becomes a sinful city, where prostitution, bars, nightclubs, horse tracks, and massage parlors mushroom all over the place. Haun, a tricycle driver, sadly observes the change:

He was glad like everybody else the day the whites came to this land. He watched the new days coming with pleasure. As modernization swept in, the quietude and the outdated were driven away.

The vast airfield was built along with a military base. Only then did Koraj become a new city and was proudly placed along side Bangkok. GIs moved around like ants; strangers flocked in like treasure hunters.

He saw old buildings demolished, row houses torn down, and slums razed. The poor were expelled. Soon attractive new skyscrapers appeared everywhere.

What was called 'development' spread faster than fire (Korn Krailard, 1972:33).

Day in and day out, Haun's customers are prostitutes and American soldiers, gamblers, and barflies. He thinks: 'The place was messed up like feces. What in need is neglected; only the eagerness to promote lust and sex. How can we survive?' (Korn Krailard, 1972:35)

The city changes physically and morally. The theme of moral degeneration is often pondered over by writers. One common issue is the exploration of prostitutes' lives. Korn Krailard, Suchart Sawadsi, and Surachai Chantimatorn are among writers at the time whose works are concerned with prostitutes, such as 'The End is Near' 
and 'One Living Thing' by Korn Krailard, and 'He and I', and 'War' by Suchart Sawadsi.

The issue of prostitution is often exposed along with the dirty, corrupted, nauseating atmosphere of the city. In ' $\mathrm{He}$ and I' (1969), the narrator walks into a slum to pay a call on prostitutes:

There was a noisy brag. The smell of liquor and vomit was in the air. He looked around; the walls of the nearby houses smelt musty. $\mathrm{He}$ could sense that filth was jumping on people who might not realize the existence of it. [...] The stench of a rotting rat mixed with that of waste water made him feel sick the whole time. He swerved, nearly bumped into a woman who had bad breath. The dim light made her face yellowish pale. He saw her thick eyebrows, and hopelessness in her lips and eyes (Suchart Sawadsi, 1972:79).

In 'One Living Thing' (1973), collected in The Memoir of A Man Called Pung, the narrator calls at a brothel. When he gets into a room he describes the nauseating state of the room: 'The mattress smelt sour; the residues from the previous intercourse were still there. The pillows had the odor of mixed kinds of hair cream'. He lies on the bed and realizes that the prostitute is very young; he feels sad:

Did it ever cross her mind, when she was eight years old, that eight years later she would prostitute herself and sleep with several men in one night? Who would understand this change? The unpredictable change in the course of life indeed. Did she long for the sweet past? (Korn Krailard, 1974:34)

One might argue that prostitution had become a common issue since the appearance of several works by Rong Wongsawan in 1960. Although the content concerning prostitution in the 1960 and 1970 works is similar, the styles are different. Rather than focusing on the story of how one becomes a prostitute or the brutality of the sex trade, the 1970 short stories concentrate on the introspection of the protagonists, both the prostitute and the customer. By adopting the experimental modes of expression of modernist works, Thai writers gradually developed the exploration of the mental process and the stream-of-consciousness as modes of expression.

\section{Lost in the City: Isolation and Alienation among the Crowd}

The transformation of a city into a metropolitan center is often discussed as the source of certain themes in art and thought. The most important theme is the lonely and isolated individual within the crowd. This irony has been discussed by Friedrich Engels, German socialist, as follows:

[...] They crowd by one another as though they had nothing in common, nothing to do with one another $[\ldots]$ The brutal indifference, the unfeeling isolation of each in private interest becomes the more repellent and offensive, the more these individuals are crowded together, within a limited space. And, however much one can be aware that this isolation of the individual, this narrow seeking is the fundamental principal of our 
society everywhere, it is nowhere so shamelessly barefaced, so selfconscious as just here in the crowding of the great city. The dissolution of mankind into nomads [...] is here carried out to its utmost extremes (Friedrich Engels, The Condition of the Working Class in England in 1844, cited in Williams, 1989:41).

In 'The Ideology of Modernism', an essay included in The Meaning of Contemporary Realism (1955), Georg Lukács, the Hungarian Marxist critic, attacks modernism as bourgeois literature, whose ontological view is different from realist literature: 'Man, for these writers, is by nature solitary, asocial, unable to enter into relationships with other human beings' (Lodge, 1972:476).

He relates the ideas of modernism with Martin Heidegger's ${ }^{5}$ description of human existence as a 'thrownness-into-being' and in turn clarifies the characteristics of modernist protagonists. He describes the issue further as follows:

Man is 'thrown-into-being.' This implies, not merely that man is constitutionally unable to establish relationships with things or persons outside himself, but also that it is impossible to determine theoretically the origin and goal of human existence (Lodge, 1972:477).

\footnotetext{
5 Martin Heidegger (1889-1976), eminent German critic of metaphysics. His crucial argument is what he calls 'the being of Being'. His main work, Being and Time, reawakens an understanding of Being and a fundamental interpretation of time.
}

Since Heidegger undervalues historicity, Lukács concludes that the two different forms of modernist literature can clearly be seen: 'first, the hero is strictly confined within the limits of his own experience [...]. Secondly, the hero himself is without personal history. $\mathrm{He}$ is 'thrown-into-theworld': meaninglessly, unfathomably' (Lodge, 1972:477).

The modernist view of human beings is thus a negative one. A modernist individual negates reality and is lost within his own self, as Lukács puts it: 'he is as inexplicable to others as to himself' (Lodge, 1972:480).

The modernist themes of bleakness, alienation, disintegration, and nihilism, gradually began to appear in Thai short stories. The themes of alienation and bleakness from a changed society were rarely presented in Thai literature before this. But in the 1970s, these themes were found in small magazines. This contemporary 'human condition' felt by students was undervalued by the literary circle as 'literature of grievances' (Satien Chantimatorn, 1982:397). Though regarded with contempt, these new literary works were later widely accepted and became common phenomena.

Isolation and alienation become major themes in young writers' works, subsequently known as 'literature of selfsearch.' The nature of the characters in these short stories is what Lukács calls 'a thrownness-into-being.' They are nobody; no backgrounds are given. Typically they are migrants from provinces living in the big city either to study or to work at lowpaid jobs; each lives alone in a small rented room and feels alienated from the world around him. Most stories are an ntrospection into the protagonist's self, wondering who he is, what is the meaning 
of life, or what is the goal of existence. A protagonist in 'Tears and Agony' (1969) by Tanya Chunchadathan talks about his life in a conversation with a friend:

I knew tears and agony, but not from injustice. I cried and was in pain when I found that I was hardly a human in this world but a lump. I was distressed and lonely, like I was left alone in this world. Why was I born? Why did I have to witness all this? Who would save me from this torment? (Tanya Chunchadathan, 1974:23).

Likewise, the themes of the short stories by Surachai Chantimatorn, a well-known writer, composer and singer, revolve around alienation and loneliness. In an interview he discloses his hardship and lonesome condition while living in Bangkok, from which derive his biographical stories: 'The Lonely Man' (in Where Are We Going?), 'The Cat and the Recluse', and 'The Yellow Bird' (in From the Plateau) (Chukiat Chataisong, 2005:166, 197).

In 'The Lonely Man' (1968), two students go to an old coffee shop. They want to drink but can afford only coffee. They talk about the loneliness of city life, poverty, and their childhood happiness. Afterward, the shop gets crowded and people enjoy themselves eating, drinking, and laughing; they all seem happy. One of the students is suddenly speechless and his eyes fill with tears. The story focuses on sensory and impressionistic description: the sound of the moving bus, the whispered conversation, and the ticking clock, and the vapor of coffee and milk. This story is a good example of 'isolation and alienation among the crowd'.
'The Cat and the Recluse' (1969) is about a young man who lives alone in a rented room. The only company that he has is a thin cat. Since he has no food to feed it he starts to kill lizards in his room with a slingshot and lets the cat eat them. Soon, there are no lizards left. One day he takes the cat to a food stall and lets the cat scavenge for food. The cat is chased away by the cook and gets hit by the car. While people at the food stall are satisfied with the death of the cat, the young man standing at the corner of the stall bursts into tears.

'The Yellow Bird' (1969) reveals the thoughts of a man who feels sorry for himself. After failing to find comfort and understanding from people around him, he chooses to live in seclusion. When he falls asleep, he dreams of an angel who consoles him and shares secrets and thoughts with him. When he wakes up, he feels better knowing that the angel will come back whenever in need.

In the collection So I Came to Find the Meaning by Witayakorn Chiangkul, the theme of alienation is repeatedly expressed. 'A Telephone Conversation in a Lonely Night' (1969) treats the subject in a telephone conversation between two strangers, a man and a woman. Without knowing each other, they each feel at ease to open their hearts to a complete stranger:

- Many people in the world may be trying to reach for someone or need a friend. But they can never be friends. It's like something is in between. Formerly we might think that what prevented one from getting to know each other are race, language, religion, culture, or social class. Now it 
is something else. Something we cannot find the answer.

- Is it because we distrust each other? (Witayakorn Chiangkul, 1997:71)

'The Road That Leads to Death' (1970), by the same author, is another example of an alienated and lonely protagonist who cannot find any meaning in life. Since he has no money and no friends with whom to share his feelings, he decides to commit suicide by jumping from a high bridge. Once he gets on the bridge ready to jump, passersby start to gather and watch him: 'nobody smiles, befriends, or sympathizes, nothing in their eyes or manners. They are just spectators, spectators with free tickets to a play they've never seen before' (Witayakorn Chiangkul, 1997:70). He feels nausea because of his fellow countrymen who are anxious to see him jump to his death. Refusing to entertain the crowd, he steps down from the rail of the bridge and feels happy to have disappointed them.

In 'One Day', a short story by Wiraprawat Wongpaupan, the narrator works in an office in the city. He describes the daily lifeless condition: 'I accelerated my pace aimlessly along the sidewalk; the road was jam packed and people walked past me with sullen looks and machine-like disposition' (Wiraprawat Wongpaupan, 1971:222). The narrator goes on to describe the dehumanized condition in the office as follows:

The ring shrieked so loud that I startled. My colleagues who were working in the same room got up almost at the same time. It was like their digestive enzymes were secreted, like guinea pigs, as soon as the ring went off. [...] A swarm of people poured out of the eighth floor office and walked along the narrow white-walled corridor. I followed the flow like a twig in a stream. I didn't know these people, though I had seen some of them around. We worked in the same building, on the same floor, and yet one was so busy with one's own life that it was a luxury getting to know one another (Wiraprawat Wongpaupan, 1971:222).

The congestion of city life and the image of skyscrapers make him see buildings as frames that confine him inside. The daily routine of work and the boredom of life are accentuated by the surrealistic image:

I stood in front of a big looking glass, looked at it, nothing. The looking glass was not reflecting any living thing. I looked into it and felt sad about my fate. Soon I would not remember my own face. The memory of myself would fade away; and finally nothing was left for me (Wiraprawat Wongpaupan, 1971:225).

Being frustrated and angry at life, some characters in these stories react violently. In 'Let's Play Games' (1971), the protagonist sits idly in a room alone. A little bird flies into the room and tries to find a way out. With a slingshot he aims at the poor bird repeatedly. When it is exhausted and flies low, he throws a towel at it: 'The final chapter finally came to the little bird. Tired, it squeezed itself in the corner of the room. The note of alarm of the bird could be clearly seen. He sympathized it and swore that he would be kind to it. 'A brutal games,' he said to himself. 'I have to catch you first, and then let you go' (Surachai Chantimatorn, 1997:132). In the end, when he sets it free, it falls into the river. The fate of the bird is like that of a man who is 
trapped in a narrow space. The more one struggles, the more one loses oneself.

\section{Where Do We Come From? What Are We? Where Are We Going?}

As one feels like being 'thrown-into-theworld,' life becomes meaningless when the aim of life is nowhere to be found. What Raymond Williams suggests is quite relevant to what the protagonists in Thai short stories try to find but fail. '(Modernism) always more recognized by what they are breaking from than by what, in any simple way, they are breaking towards' (Raymond Williams, 1989:43).

In 'The Road That Leads to Death' (1970) by Witayakorn Chiangkul, the protagonist wants to commit suicide because life is meaningless: 'I didn't see any reason to live. And I didn't know what was the meaning of existence. I once asked some acquaintances about this, those imbeciles were born just to idle away their lives' (Witayakorn Chiangkul, 1997:72).

In 'The Yellow Bird' (1969), the protagonist is obsessed with the question of who he is:

I, Tongsen Jenjud, who am I? A human being? Maybe not. Some might not think I'm human. Who am I? No, I don't know. A mad man? No. If I am mad, I'm a man. Everyone is mad. I am what I am. No. I don't have what deserves to be me like I want it to be. A man? I don't want to be a man. A democratic, a communist. No. I am tired of this feeling and this existence. I want to be that bird. Do you hear me, yellow bird? (Surachai Chantimathorn, 1997:72).

The protagonists of these stories try to find the answers to a lot of questions and are never satisfied. It is as though what lies in front is the void. In 'The Wall' (1970) written by Suchart Sawadsi, the protagonist asks:

Damned! Maybe because I had freedom and I might be so oppressed by the repetitious life that I didn't know where to go or what to do. And I was in no position to be envious of the past 35 years of my life. This was the assumption to be declared in the memoir. You might find the value of life; but it was still confusing. The petty inconvenience of the repetition (no need to have the conscience of what is right and wrong) made me think that life is not livable. Or at least it was because I could not find happiness (Suchart Sawadsi, 1972:150).

It is notable that the narration of this topic is quite hard for the reader to handle, since what these characters want is the unidentified; or as Williams concludes, modernist works do not show what they are breaking towards, so the problem of unintelligibility occurs.

Some works show that young people start to question the coercion used by autocratic rules. The protagonist of Komsorn Kunadilok's 'A Walk in a Night' (1970) asks:

In front of me was a crossroad; here was the green light, and there the red. There was a car stopping at the red light. Why didn't I cross the street and go 
straight? Why didn't I turn left or go back where I came from? My house was on the right; that was where my parents were. If I asked the professors at the college, they would tell me to turn right. My friends would turn right too (Komsorn Kunadilok, 1992:38).

The protagonist asks himself why he has to go where everybody goes, implying the political conflict at the time of the Cold War. To go 'left' or 'right' is in question. This means that although these young people do not know what they are going toward, they surely know what they are against.

The questions 'where do we come from? what are we? where are we going?' are found in many short stories. Like other protagonists discussed so far, the protagonist in 'To Die in the Sea' (1972) by Suwat Srichua decides to drown himself in the sea. But before that, he goes to a brothel. Later, he and a prostitute have a rather philosophical conversation:

'Where do you come from?' she asked me.

'I don't know,' I answered.

'Why are you here?' she asked.

'I don't know,' I answered. She looked upset.

'Where are you going?' ${ }^{\prime}$ she asked me again.

'I don't know,' I answered truthfully

(Suwat Srichua, 1975:10).

The questions are used as the title of a short story by Suchart Sawadsi, with a slight modification: Where do we come from? How do we come here? Where are

\footnotetext{
${ }^{6}$ Emphasized by the author, Suwat Srichau.
}

we going? (1969). Written by the same author, the questions appear once again in another short story called 'A Journey to the Fields' (1970). But this time they are found in a conversation between the protagonist and an imaginary woman. The questions arise again in the beginning of another short story, 'The Journey Inside' (1972) by Tanong Pisan. Some information about the origin of these recurring questions is also given:

The thunderous yet sad song was playing with strong beats, calling for a violent change of the world. This crude, melancholic, sincere song could be compared to a type of painting called 'fauvism,' where unrestrained feelings are expressed. I tried to find the meaning of a painting called 'Where do we come from? What are we? Where are we going?' It was painted by an artist who searched for the meaning of art and life in the South Sea. Before creating this work he had seen the death of an empty and meaningless life. He then planned to commit suicide, which was what many might want to do. 'Before I die, I will paint a big picture telling what I think.' To his disappointment, the plan failed (Tanong Pisan, 1972:62).

The artist who painted a work called 'Where do we come from? What are we? Where are we going?' (1897-1898) is Paul Gauguin, a post-impressionist painter. After a failed attempt to take his own life, he wants to paint what he confronted, death's abyss. The painting depicts dramatic personae: children, figures, farm animals, old women, an idol, who offer a symbolic interpretation of everyday life, 
destiny, death, and the beyond (Eisenman, 1997:135). The title and the meaning of the painting must have impressed many Thai writers and must have led them to question the meaning and the purpose of life, also showing the interest of these writers in art.

The idea that life is meaningless also leads to the issue of death. As discussed earlier, while some stories show that the characters are desirous of committing suicide, others offer contemplation on death, like the works of Surachai Chantimatorn: 'The Dumb City' and 'The Music of Death'. In 'The Dumb City' (1968), the character gets a telegram announcing the death of his beloved grandmother. While drinking with his friends, he is occupied with the thought of old people and death. At the end of the story he decides not to go home because he has no money. 'The Music of Death' (1969) also deals with mortality. The protagonist is a musician in a Thai ensemble hired to perform at a funeral. $\mathrm{He}$ is depressed by the sad scene but finally he concludes that a human being is actually confined in his body; and one should be happy to die and experience the freedom beyond the world of flesh. ${ }^{7}$

The protagonist of 'One Day at the Graveyard' (1973) by Korn Krailad, when seeing the funeral procession, ponders on the meaning of life: 'What exactly is life? I don't understand. Sometime I sat silently and watched the crowd in different posture.

\footnotetext{
${ }^{7}$ The idea of the inalienability of death is a proposal of Heidegger in Being and Time, as he puts it: 'all authentic being is a being - towards its own - end' (Steiner, 1978:101). Whether Thai writers were influenced by Heidegger is still in question. But it is apparent that names and works of some Western philosophers, notably Nietzche and Satre, are mentioned in the works of Thai writers in this period.
}

Who are we? Where do we come from?' (Korn Krailad, 1974:41). Again, philosophical questions arise. One day the protagonist wanders into a graveyard and reads the epitaphs on the headstones. Thinking about the life of one of the deceased, he wonders:

He might have died in an accident, or he might have killed himself out of boredom of life. He might have thought that he had lived in a repulsive period. $\mathrm{He}$ might have been disturbed and inflamed by social ills. His contemporaries were weak and conformed to the flow. In the end he might have been bored with everything, including life itself. So at one moment on New Year Day, he committed suicide (Korn Krailad, 1973:42).

The contemplation of the protagonist reflects the contemporary attitudes of young people at that time who were tired of the social and political atmosphere and felt helpless.

\section{Life is a Nightmare}

The combination of stress, loneliness, delirium, and insanity can be brought to the extreme in modernist works, as Raymond Williams puts it: 'But more generally important is the extension of the association between isolation and the city to alienation in its most subjective sense: a range from dream or nightmare [...] through the distortion of opium or alcohol, to actual insanity' (Raymond Williams, 1989:40). Georg Lukács, in 'The Ideology of Modernism' discussed earlier, also points out that the lack of objectivity in the description of the outer world leads to the reduction of the reality into a nightmare. 
This topic is obvious in the works of Kafka, Beckett, and Faulkner (Lodge, 1972:484).

Some Thai short stories in this period offer the depiction of the protagonists' nightmares; others show the distortion of the mind.

The protagonist in 'A Journey to the Fields' (1970) by Suchart Sawadsi tells his dream to an imaginary woman:

I dreamed that I started walking to the fields, stepping on the green grass. I walked up the hill; along the sandy path were the sano trees. When I walked down the hill I felt the blood on my feet. The green grass was gradually covered with blood running down from my body. [...]. The bleeding continued but I didn't feel anything. When I was walking, I was not even sure whose blood was it (Suchart Sawadsi, 1972:122).

In 'Flight' (1966) by Prapan Ponsawake, the protagonist flees after stabbing someone. He starts feeling paranoid and is convinced someone is following him. $\mathrm{He}$ looks around and sees nobody. In the end, he finds out that a gigantic pair of eyes are following him. He then runs for his life but is sucked into the eyes (Suchart Sawadsi, 1975).

In 'A Cruel Night, An Empty Day' (1973) by Visa Kantap, a young man locks himself in his room because he has no where else to go. He feels tired after having had to work the whole week, and the next day is Monday again: 'Tomorrow is the confused Monday, the first day of the week, next is the tired Tuesday, the cranky Wednesday, the boring Thursday, the failed Friday, the carefree Saturday, and finally, the empty Sunday again' (Suchart Sawadsi, 1975:260). With nothing else to do, he smokes marijuana and gets high. Later, he lights a candle and finds three dolls in the room. He drops the melting wax from the candle onto the dolls. He drops wax in the eyes of the first doll because its eyes challenge him and in the mouth of the second because it looks deceitful. He then burns them all. Seeing the dolls writhing in agony, he helplessly watches them walking toward him.

Thus some characters in these short stories find comfort only in dreams, while others use drugs to escape reality, both leading to illusion and delusion. Christopher Butler points out that in modernist works, the distortion of reality occurs when one's subjectivity is threatened by the overwhelming and machine-like activities of city life; thus one cannot maintain oneself under this impact (Butler, 1994:134).

\section{The Inward Turn}

As loners in the city, these characters are left alone in a narrow room. Some stories show the protagonist wandering alone at night along a deserted street. All present the concept of enclosure, not only geographically, but psychologically or spiritually.

As a scholar of modernism, Frederick Karl's focus of attention is the concept of 'enclosure' in modernist works. $\mathrm{He}$ proposes that enclosure is basically a spatial metaphor for recessiveness, expressed by withdrawal into rooms, mazes, and labyrinths. Enclosure images in modernist works suggest inwardness, as does the technique of stream-of-consciousness. These images are efforts to capture 
physically that inwardness which the stream-of-consciousness attempts to capture in words (Frederick Karl, 1985:240-241).

It should be obvious by now that all Thai short stories discussed so far express the characters' frustration or withdrawal, the machine-like activities, and the depersonalization of life in the city. What is most interesting is the change in the narrative style: from linear, progressive style and plot determination to introspection and reflection. The techniques chosen in these short stories to express the subject matters are 'interior monologue' to render the thoughts of characters. But some writers take it further by using stream-of-consciousness, which is the discontinuity of thoughts, memories, reflections and sensations, as Astradur Eysteinsson suggests in The Concept of Modernism:

[...] modernism is judged not as an aesthetic complement of social modernity, but rather as a vehicle of crisis within the 'progress' of modernization. The sign of this crisis are generally felt to reside in a modernist preoccupation with human consciousness, [...] and they are perhaps most pronounced in the 'stream of consciousness' technique in modernist fiction (Eysteinsson, 1990:26).

One of the central achievements of modernism, stream of consciousness was considered a technical breakthrough as a forceful expression of thought (Stevenson, 1992:39). In Thai literature, stream-ofconsciousness can be found in many Thai short stories written between 1969-1973.
We can see an example of stream-ofconsciousness narrative in the thoughts of a character in 'The Silence' by Suchart Sawadsi. The passage suggests how the mind flows freely and abrupt thoughts are juxtaposed arbitrarily to mimic the mental habits of the character:

I always thought that if I wrote a novel, it would be a scene I was looking at. But it was impossible to do, especially the plot and the characterization. I look at the woman sitting alone at the corner; what is she thinking? She might be waiting for someone. What kind of people are the bad guys? And those who are attached to each other? Those in love must be happy. But I am lonely. That tree pot shouldn't block the sight of her. I believe I can write about her in the story. She might not be mine, but I can make her come into existence. [...] Maybe the machines would conquer the world in the next epoch. Look at the annoying flies; a coffee shop will not be one without flies. The drinks last night made me a little tired (Suchart Sawadsi, 1972:95).

The same style can be found in 'From the Urine-Colored Room' (1973) by Tanong Pisan. The story revolves around the confusing thoughts of the protagonist called 'Rawai', who feels alienated from his job and the town where he works. His thoughts, which are about the question of who he is, his beloved friends, his loneliness, clippings from books and films, an imagination of a woman covered with blood, a water buffalo sunbathing in a pool of mud, etc., are unrelated fragments but intelligible. However, the culmination at the end of the story is quite unreadable: 
The field under the strong sun. The water buffalo in the pool of mud. The smile of the victor. The urine rapidly flows and smells in the drainage model. A fair equality [...] A girl with dull skin and messy hair sits on the back of a buffalo singing lively. I spit and curse. Double standard. Veera walks along the canal slowly. It will show the meaning if it finally happens. Don't let it die like that. I sit against the wall. Like something is haunting this room (Suchart Sawadsi, 1975:246).

These fragments of thoughts, which occur in the beginning of the story, appear rapidly one after another up to the end of the story, forming a film-like impression for the reader.

\section{The Shattered Entity}

In fact, the rendering of thoughts in the form of interior monologue and stream-ofconsciousness that lead to unrelated and fragmented images is similar to the techniques of collage and montage.

A device typical of Cubist paintings, collage is the technique by which unrelated materials, such as cloth, wood, and newspaper clippings, are pasted together on a surface. In literature, collage refers to words or passages not usually associated put together to create a certain impact upon the reader. Whereas montage, created in filmmaking, is a method of rhythmic pacing of shots, the rapid transition from shot to shot produces a particular effect. In literature it means a series of brief pictures following one another quickly without an apparent order (Holman and Harmon, 1992:93, 301).
Borrowed from painting and film respectively, collage and montage are the techniques of the modern, as Christopher Butler, when discussing the relationship between literature and the arts, says of montage: 'An inability to make those explanatory patterns which most easily arise from the habitual leads, $[\ldots]$, to the representation of urban experience by montage techniques' (Christopher Butler, 1994:134).

As modes of representation, collage and montage escape from linear rendering to creation of fragments. By cutting causal events into pieces and placing them arbitrarily or putting bits and pieces of quotations, newspaper clippings, allusions, advertisements, etc. together, new styles of writing take shape and form experimental fiction.

The experimental styles of collage and montage were quite new to the Thai literary circle at a time when the unity of plot structure was a must for the short story writing standard. But some of the Thai short stories emphasize the chaotic and hectic life of the cities with both techniques. The end of the story 'From the Urine-Colored Room', discussed above, is, therefore, presented with the montage technique, where each shot follows one another rapidly.

The narrative of the short story 'Complexity and Confusion' (1970) by Korn Krailad is presented in a similar way. But the technique of montage is used in the narrative structure rather than in one paragraph as in 'From the Urine-Colored Room'.

'Complexity and Confusion' is a picture of a chaotic city: boys running up and down 
the streets selling newspapers, female passersby in short skirts, a crippled beggar, a dirty stray dog, a group of intellectuals drinking and cursing the unfairness of the country, teenagers disappearing into a department store selling foreign goods, a traffic jam, a body falling from a moving bus, a voice of a mother consoling her child. All are connected forming the scenes that an old and experienced woman walks through.

Thus, the story has no plot. The shots following one after another can be explained as a montage because they are only a collection of scenes portraying the chaotic life of Bangkok witnessed by the indifferent old woman.

'The Silence' by Suchart Sawadsi is presented in a similar fragmented style but the technique is close to collage.

'The Silence' applies the narrative style of drama, while the characters' thoughts are also presented between dialogues. The story begins with the scene of a woman and a man sitting in a canteen. She has just learned that she is pregnant. She seeks help from her male friend, but from the conversation he apparently does not care much and is quite annoyed with the woman's problem. He does not want to interfere because it is none of his business. Then the scene shifts to a waiter who is busy finding the right channel on a radio; he thinks of immorality when seeing a nude poster and hearing obscene songs. He also thinks about his customers who are mostly students as he watches the woman and the man in the canteen. Then the voice from the radio is heard, reporting the situation in the Vietnam War and the government's propaganda accusing the leftists. Next are the disorderly thoughts of a student who looks at the woman (his confusing thoughts discussed earlier as stream-ofconsciousness). The story ends with the voice from the radio reporting the number of casualties in the Vietnam War (Suchart Sawadsi, 2515:82-96).

These scenes presented alternately are barely related. The fragments of the scenes, the conversation between the man and the women, the thoughts of the waiter, the thoughts of the student, the news of the Vietnam War, are pieced together. The story thus resembles a collage, where pieces of dissociated materials are combined. The story shows the ignorance of the Thai people about the Vietnam War, because everyone is busy with his/her life, while the tragic war is around the corner. The story should have been a strong criticism of the War and censored at that time. But its unintelligible style allowed it to slip through the autocratic net.

Another example of collage is 'Filth' (1972), written by Tongchai Suragan. The narrator is waiting for a bus late at night and thinking about the hypocrisy of the older generation. He thinks that he has been deceived in playing some dirty games, so he wants to get out of it. To kill time he reads a newspaper. So the story moves on with the news and the articles he reads: President Nixon of the United States visiting China, the attack of communists on a village in Thailand, social news of high society, readers' complaints about the economy and corruption, readers' letters seeking advice on their love life, U.S. operations in Vietnam War, casualties in Vietnam. Then a street cleaner comes by and they have a brief conversation about life. The narrator decides to go back to the dirty games and throws the newspaper in the trash. 
Similar in content and style to 'The Silence', 'Filth' is not only critical of the Vietnam War, but also of the government, the social and economic malaise. The technique of collage in this story is quite apparent, since the fragments are taken from news reports and articles in the newspapers.

Fragmentation is not only found in plot structure but also in the presentation of the leading characters. The technique used is the alteration of perspective which depicts the confused mind and the alternated personality. In 'He and I' (1969) by Suchart Sawadsi, the first person narrator ' $\mathrm{I}$ ' is in a lecture room but his mind wanders; he thinks of his past, of women, of life and death. He thinks of his friend who earlier has brought back a woman, probably a prostitute, to their room, which upsets him.

From the room he can see a temple; so he thinks of visiting one. Then the story changes perspective to that of the third person describing the thoughts of ' $\mathrm{He}$ '. $\mathrm{He}$ is walking to a brothel. Along the path he sees the dirty surroundings and struggling life of the working class people. The story ends when he knocks on the door of a brothel.

The change of perspective in this story is not entirely new. But as the reader continues, it is noticeable that the thought of 'going to a temple' is repeated in the mind of the third person perspective. So the story divided into two parts is actually that of the same person. The story is then about a conflict in the mind of the protagonist who tries to suppress his sexual desire but fails.

\section{Conclusion}

A considerable number of modernist Thai short stories of the 1964-1973 clearly show hostility toward urbanization. The writers use the fragmentation techniques of collage and montage to great effect to depict the confusing, overcrowded, and chaotic images of the city. Lonely characters alienated from their surroundings shut themselves up in rooms and are lost in their thoughts. All subtly portray the tumultuous life in the city where one's 'self' is being threatened.

\section{References}

Bradbury, Malcolm and McFarlane, James. 1985. Modernism 18901930. New York: Penguin Books.

Butler, Christopher. 1994. Early Modernism: Literature, Music and Painting in Europe 1900-1916. Oxford: Oxford University Press.

Childs, Peter. 2000. Modernism. New York: Routledge.

Chukiat Chataisong. 2005. Born When God Is Sleeping. Bangkok: Samanchon. [in Thai]

Eisenman, Stephen. 1997. Gauguin’s Skirt. London: Thames and Hudson.

Eysteinsson, Astradur. 1990. The Concept of Modernism. Ithaca: Cornell University Press.

Holman, C. Hugh and Harmon, William. 1992. A Handbook to Literature. $6^{\text {th }}$ ed. New York: Macmillan. 
Karl, Frederick R. 1985. Modern and Modernism: The Sovereignty of the Artists 1885-1925. New York: Atheneum.

Komsorn Kunadilok. 1992. A Walk in a Night. Bangkok: Smit. [in Thai]

Korn Krailad. 1972. A Golden Flower. $2^{\text {nd }}$ ed. Bangkok: Panfa Pittaya. [in Thai]

Korn Krailad. 1974. The Memoir of A Man Called Pung. Bangkok: Non. [in Thai]

Likit Dhiravegin. 1985. Thai Politics: Selected Aspects of Development and Change. Bangkok: TriSciences. [in Thai]

Lodge, David. 1972. 20 $0^{\text {th }}$ Century Literary Criticism. London: Longman.

Ortega y Gasset, José. 1968. The

Dehumanization of Arts. Princeton: Princeton University Press.

Rong Wongsawan. 1988. Climbing Up the Canal Banks. $3^{\text {rd }}$ ed. Bangkok: Kon Wannakum. [in Thai]

Rong Wongsawan. 2004. The Carefree Peasants. $7^{\text {th }}$ ed. Bangkok: Praew Press. [in Thai]

Satien Chantimatorn. 1982. The Stream of Thai Literature for the Masses. Bangkok: Chao Phraya. [in Thai]

Steiner, George. 1978. Heidegger. Sussex: Harvester Press.
Stevenson, Randall. 1992. Modernist Fiction: An Introduction. Lexington: University Press of Kentucky.

Suchart Sawadsi. 1972. The Silence. Bangkok: Nangsue. [in Thai]

Suchart Sawadsi (ed.). 1975. The Road That Leads to Death. Bangkok: Duang Kamol. [in Thai]

Suchart Sawadsi (ed.). 1975. Harsh Drought. Bangkok: Duang Kamol. [in Thai]

Suchart Sawadsi (ed.). 1976. The Response. Bangkok: Duang Kamol. [in Thai]

Suchart Sawadsi (ed.). 1976. Like It Has Never Been Done Before. Bangkok: Duang Kamol. [in Thai]

Surachai Chantimatorn. 1996. From the Plateau. 10th ed. Bangkok: Samanchon. [in Thai]

Surachai Chantimatorn. 1997. Visited by Madness. $10^{\text {th }}$ ed. Bangkok: Samanchon. [in Thai]

Surachai Chantimatorn. 1997. Where Are We Going? $10^{\text {th }}$ ed. Bangkok: Samanchon. [in Thai]

Suwat Srichau. 1975. War in the Grave. Bangkok: Prapansarn. [in Thai]

Tanon Pisan. 1972. The Journey Inside. Sangkom Sart Paritad. 10.3:62-71. [in Thai]

Tanya Chunchadathan. 1974. His Nullified Life. Bangkok: Chareonwit. [in Thai] 
MANUSYA: Journal of Humanities (Special Issue No.10 2005)

Tongchai Surakan. 1972. Filth. Sangkom

Sart Paritad. 10.9:82-87. [in Thai]

Williams, Raymond. 1989. The Politics of Modernism: Against the New

Conformist. New York: Verso.

Wiraprawat Wongpaupan. 1971. One Day. In A Collection of Short Stories by Num Nau Sao Sauy and Prajun Saew. Bangkok: Prapansarn. [in Thai]

Wittayakorn Chiangkul. 1990. So I Came to Find the Meaning. $10^{\text {th }}$ ed.

Bangkok: Samanchon. [in Thai] 